\title{
Geosynclines and Petroliferous Deposits
}

(A Contribution to the Study of the Relations between Earth Movements and Hydrocarbon Accumulations)

BY MARCEL R. DALY, SEATTLE, WASH.

(St. Louis Meeting, Ootober, 1917)

IN a preceding paper ${ }^{1}$ the writer has pointed out some apparent relationship between the distribution, on the surface of the globe, of the known hydrocarbon deposits and the disposition of the principal zones of deformation of the earth's body (geosynclines). He wishes to present some further remarks on this subject.

Petroleum deposits, or their derivatives or descendants, are found through the whole range of sedimentary strata, from the pre-Cambrian to the Quaternary. For instance, the pro-Beltian (Shuswap) series of the Canadian Cordillera are interbedded with limestones which are sometimes rich in carbonaceous matter (Sicamous limostone); and the Beltian system of the same region contains layers of argillitos and dolomitic limestones which are equally high in carbon content. ${ }^{2}$ This carbon may be interpreted as the last remnant of hydrocarbons previously contained in the rocks. On the other hand, the actual formation of hydrocarbons under conditions that would eventually permit their deposition in modern sediments is conceded by some geologists. ${ }^{3}$ Between these two extreme limits, bitumens are found indifferently in all sedimentaries. Thoy constitute a continuous series, some kind of a large family, whose individual members may be entitled to a community of origin and probably represent the different stages of evolution of the primitive, parent matter. The kinship between petroleum and such substances as asphalt, ozocerite, manjak, grahamite, albertite, etc., is well known; and $\mathrm{E}$. H. Cunninggam-Craig has recently shown how intimately shale fields and oil fields are connected. ${ }^{4}$ For this reason, no distinction is made in the present

1 The Diastrophic Theory. Trans. (1917), 56, 733.

${ }^{2}$ Geological Survey of Canada, Guide Book No. 8, 124 and 134.

${ }^{3}$ Sir Boverton Redwood: Petraleum (1913), 1, 133-134; Dalton: Economic Geology (1909), 4, 620; E. T. Dumble: Trans. (1914), 48, 526.

${ } \mathrm{E}$. H. Cunningham-Craig: Kerogen and Kerogen Shales. Journal of the Institution of Petroleum Technologists (1916), 2, 238-273. "Kerogen" is a term denoting the substance or substances contained in Scottish oil-shales from which oil is obtained. According to Craig, kerogen is formed by the inspissation of petroleum and by the adsorption of inspissated petroleum by argillaceous material. 
study between the different kinds of hydrocarbons and they are treated as a whole (petroliferous deposits).

James D. Dana has applied the term geosyncline to the great earth troughs that have taken place in regions of excessive deposition, and that he considers preparatory to the formation of mountain ranges. ${ }^{5}$ Subsequent writers, and especially Prof. Emile Haug, of Paris, have greatly extended the meaning of the term as well as the idea itself. Haug considers the geosynclines as zones of weakness and mobility of the earth between two stable masses (continental areas) ; ${ }^{6}$ whereas T. C. Chamberlin regards "the crumpled tracts as lying on the border of great segments of the earth that acted essentially as units."7 From a mechanical standpoint, the idea is fundamentally the same. Considered in this light, a geosyncline is no more simply the expression of a local deformation: it belongs to a general system of distortion which is world wide (network). The term geosyncline is used in this paper with this extended sense, but without any special inference as to the real nature of the intervening areas or earth segments, which is immaterial for the present discussion. Individually, geosynclines are to be considered "the sites of subsequent foldings of the strata, or, conversely, the regions of folded mountains are the sites of former geosynclines." 8 A geosyncline may be simple or compound, and is more generally compound.

It seems difficult to call in question the fact that the location as well as the trend of these world-wide zones of mobility have somewhat varied in the course of ages. For instance, Marcel Bertrand has shown ${ }^{9}$ that three successive zones of distortion have developed in northern Europe during Paleozoic and pre-Paleozoic times, progressing from North to South and giving rise to three distinct mountain chains, which would have been preceded by as many geosynclinal belts. ${ }^{10}$ On the other hand, in some regions, the general strike of the foldings seems to have remained constant during extensive periods. Thus, in British Columbia, the

5 J. D. Dana: Manual of Geology, 4th Ed., 380, 385.

- Emile Haug: Les Géosynclinaux et les Aires Continentales. Contribution à l'étude des transgressions et des régressions marines. Bulletin de la Société Géologique de France, 3 Ser. (1900), 28, 617-711; also Traité de Géologie (1908), 1.

7 T. C. Chamberlin and R. D. Salisbury: Geology, 1, 543.

${ }^{8}$ A. W. Grabau: Principles of Stratigraphy, 902.

${ }^{9}$ Bulletin de la Société Géologique de France, 3 Ser. (1887-88), 16, 576.

${ }^{10} \mathrm{M}$. Bertrand terms the first chain the Huronian. It would have extended, in pre-Cambrian times, from the Lake region of North America through the Highlands of Seotland, Norway, Sweden, Finland, and reached the extremity of Asia. Later, toward the end of the Silurian, a second chain (the Caledonian chain of Suess), would have arisen further south, and, finally, toward the end of the Carbonic, a third one, the Hercynian chain (Variscic or Armorican of Suess) would have arisen still further south, extending from southern Ireland and French Brittany, through the Vosges, the Ardennes, the Black Forest and the Hartz, to Bohemia. The Appalachian folding, which dates of this same period, would have been a link of this latter network. 
Rocky Mountain formations, above the Shuswap (pre-Beltian) series, show a Cordilleran trend throughout; and from the Beltian (pre-Cambrian) to the Permian, the enormous pile of sediments involved, more than $50,000 \mathrm{ft}$. thick, present no thoroughgoing unconformity. This would indicate, at least for this part of the Pacific Geosyncline of North America, a permanency in the direction of the strains extending through the greater part of the known history of the earth. But even there a change may be detected if we trace the movements further back; for the underlying Shuswap (pre-Beltian) strikes N. $70^{\circ}$ E., nearly at right angles to the prevalent strike of the later formations. ${ }^{11}$

Thus, in order to examine in some detail the mutual relations between geosynclinal belts and hydrocarbon (petroliferous) deposits, it would be necessary to define the different successive synclinal networks at the different periods of the earth's history and to compare them individually with the corresponding known petroliferous deposits of the same age. But this is a task which, at present, would be beyond our means, by reason of the lack of data. We are reduced to general comparisons, of widely separated periods of time. However incomplete such an examination may be, it offers, in the opinion of the writer, some conclusions of real import.

By far the great majority of the known petroliferous deposits of commercial value belong to the Mesozoic and to the Tertiary eras; or at least the sediments in which they are found date from these ages. Further, there seems to have been a certain degree of constancy, since the close of the Paleozoic, in the location and general trend of the principal areas of deformation of the globe: most of the Tertiary areas of deformation closely follow the trend of Mesozoie synclinals. Finally, the distribution and disposition of the geosynclinal belts of post-Paleozoic age are better known to us than those of the preceding eras. For these reasons, it has seemed advisable to the writer to investigate first the Mesozoic and postMesozoic periods.

The map (Fig. 1) shows the results of such an investigation. This map has been established on a Mercator projection (longitudes E. and W. of Paris). The geosynclines are those of the Mesozoic era, and are drawn according to the views of Prof. E. Haug. ${ }^{12}$ The dotted part of the outlines are those which this author considers either uncertain or hypothetical. The Mesozoic and Tertiary petroliferous deposits are represented by black dots; the Paleozoic ones by shaded areas. No attempt

11 Reginald A. Daly: Introduction to the Geology of the Cordillera. Geological Survey of Canada, Guide Book No, 8, 149 and 153. As R. A. Daly observes, this strike recalls the prevailing E. W. to $\mathrm{N}$. $60^{\circ} \mathrm{E}$. strikes in the pre-Cambrian rocks of Jake Superior and eastward thereof in the Canadian shield. It also recalls the Huronian system of M. Bertrand, and may indicate a western extension of this pre-Cambrian synclinal network.

${ }^{12}$ Bulletin de la Société Góologique de France, 3 Ser. (1900), 28. 


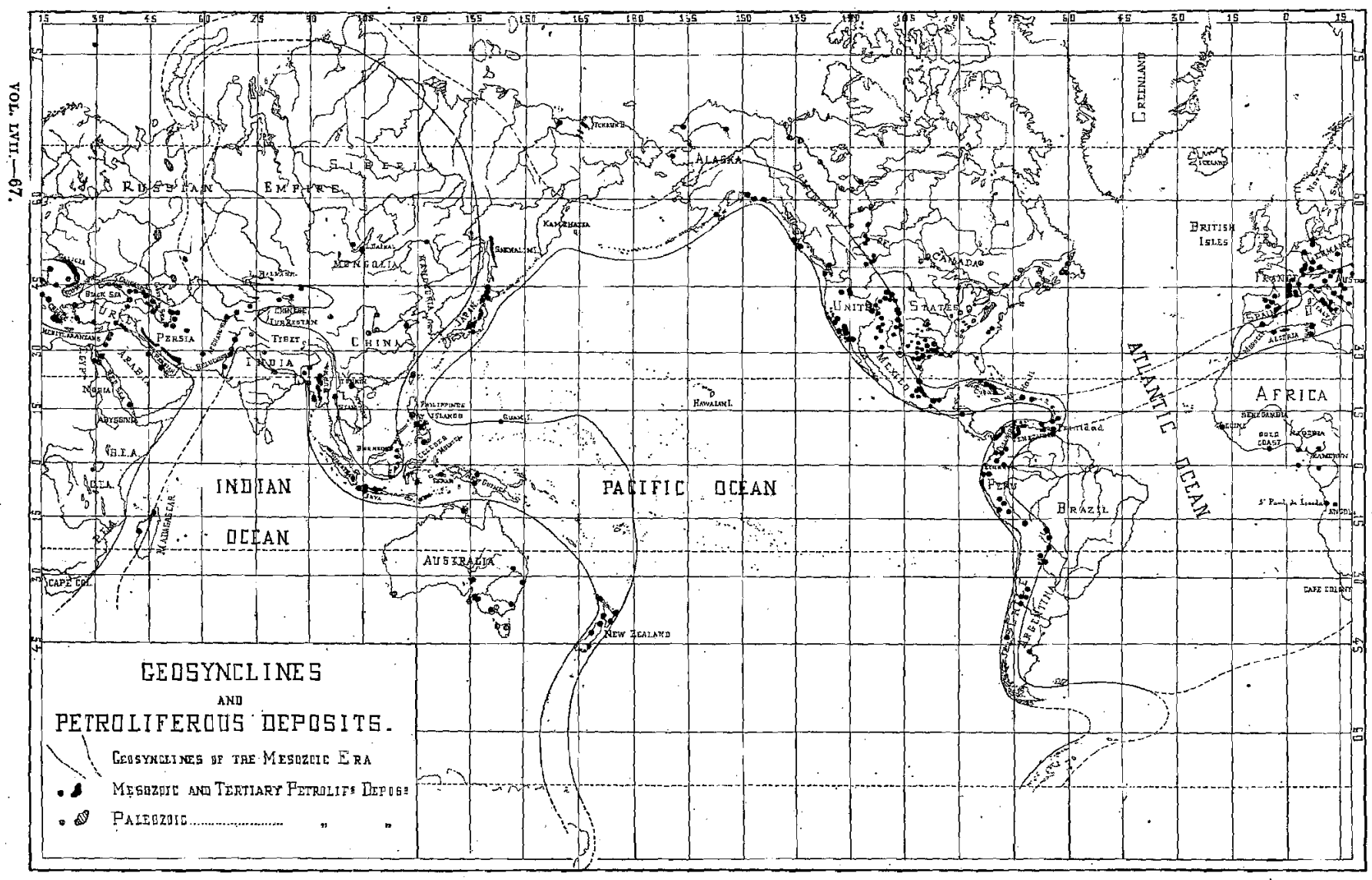

FIG. 1. 
has been made to distinguish between the various hydrocarbons nor to set off the respective importance of the deposits themselves. For the location of the deposits, use has been made of the maps published by Sir Boverton Redwood in his treatise on petroleum, and of the publications of the Geological: Surveys of the United States, Canada, India, and others available to the writer.

The aim of this map is to present general information rather than to give data correct in overy detail. The limits of a geosyncline can hardly be determined with any degree of geometric accuracy. The principal areas of dislocation and folding of a region are defined, but minor folds generally extend at a more or less greater distance outside of their assigned limits. As pointed out by De Launay," "the dislocations of the earth are more and more observed to have taken place not alone in mountainous regions, but even in regions of plains.". Further, it is possible that the outlines of some of the geosynclines traced on this map, a part of which are still hypothetical, would have to be corrected. With this reservation in mind, the following observations can be made.

It may be readily seen that the general sequence of the petroliferous deposits closely follows the path of the synclinal network. About 90 per cent. of the deposits are oither included between the borders of the synclinal belts or located in their immediate neighborhood. Approximately 10 per cent. only of the total is to be found at some great distance outside. Such are the deposits of the western coast of Africa, of Southern Australia, of the Red Sca, and some isolated and little known or unimportant deposits in Mongolia, Eastern Siberia (Tchaun Peninsula), and Northwestern Alaska.

The relation of the two last groups (Tchaun Pen. and N. W. Alaska) with the geosynclinal branch of the Northern Pacific is uncertain, as the northern limits of this syncline are still in doubt. The other deposits follow secondary lines of deformation, and many of these belong to this class of lines which Suess has termed "disjunctive"; viz., they are breaks that mark out zones of collapse (effondrements). Such are the fractures which have determined the curious depression of Lake Baikal, or the remarkable group of faults that extend from Syria, through the valley of the Jordan, the Dead Sea, and the Gulf of Akab, to the cliffs of Abyssinia and hence as far as the neighborhood of Mozambique. These forms are characteristic of disruptive movements having taken place through already consolidated territories, and they seem to imply the break of some fold in the process of formation through grounds that were not plastic enough to allow the completion of the folding. It is remarkable that the hydrocarbon deposits which have been found so far along these secondary lines of distortion are themselves secondary in importance,

${ }^{13}$ De Launay: La Science Gélogigue, quoted by E. Coste, Trans. (1914), 48, 514. 
when compared to many of the deposits that stake out the principal geosynclinal belt.

The result of the above is that petroliferous deposits of Mesozoic and post-Mesozoic ages are essentially distributed on the globe along the lines of dislocation characteristic of the ages, and they become thus apparently connected with the contemporaneous earth movement.

There are many reasons to think that the same conclusion would be reached from the comparison between geosynclines and petroliferous deposits of pre-Mesozoic age. Such a view is strengthened, for instance, by the general disposition of the Paleozoic deposits of North America in regard to the Appalachain belt of deformation, from the basin of the St. Lawrence to the Rocky Mountains, or along the borders of the "Canadian Shield," also by the distribution of the same kind of deposits around the "Russian platform;" and by other facts. This would imply a general law, that we may tentatively express as follows: The petroliferous deposits of any given period closely follow the principal areas of deformation of this same period.

This general, apparent relationship between the areas of distortion and the loci of deposition of the hydrocarbons, or between earth movement and petroliferous accumulations, becomes still more precise with the detailed study of certain oil regions. It is to be expected that the simpler the order of deformation, the more distinct the relations will appear. We are thus brought to consider, at first, regions where the structure is easily interpreted, or at least where it has not been obscured by the superposition of a complex series of stresses, varying in age, directtion, and intensity. The writer has pointed out such regions as the Fastern Oil Belt of the United States and the belt of the Carpathians in Central Europe, where these conditions are met. ${ }^{14}$ In the first. instance, the deformation may be interpreted as due to a single dominant thrust; in the second, the thrust would have been repeated, in the same direction, at several distinct periods. The results are represented schematically on Fig. 2 and Fig. 3. Fig. 2 shows the location of the principal oil and gas fields of Pennsylvania and their relation to the Appalachian ridges. ${ }^{15}$ Fig. 3 shows the disposition of the principal oil fields - of Galicia, and their relation to the trend of the Carpathian range. In the first case, Fig. 2, we have a sequence of simple, broad, and more or less parallel anticlines, merging into monoclines and terraces at the farther end of the distorted area. In the second (Fig. 3), a more complex structure has arisen, due to faults and overthrusts, but it is still anticlinal in its essence and is equally characterized by parallel, concentric lines of

14. Trans. (1017), 66, 735.

15 After C. A. Ashburner and J. P. Leslie: U. S. Geological Survey (1900-01), 22d Annual Report, part 3, 579. The reader is also referred to the general map of the eastern oil and gas fields near the Appalachian Basin, by David B. Reger, Trans. (1917), 66, 858. 


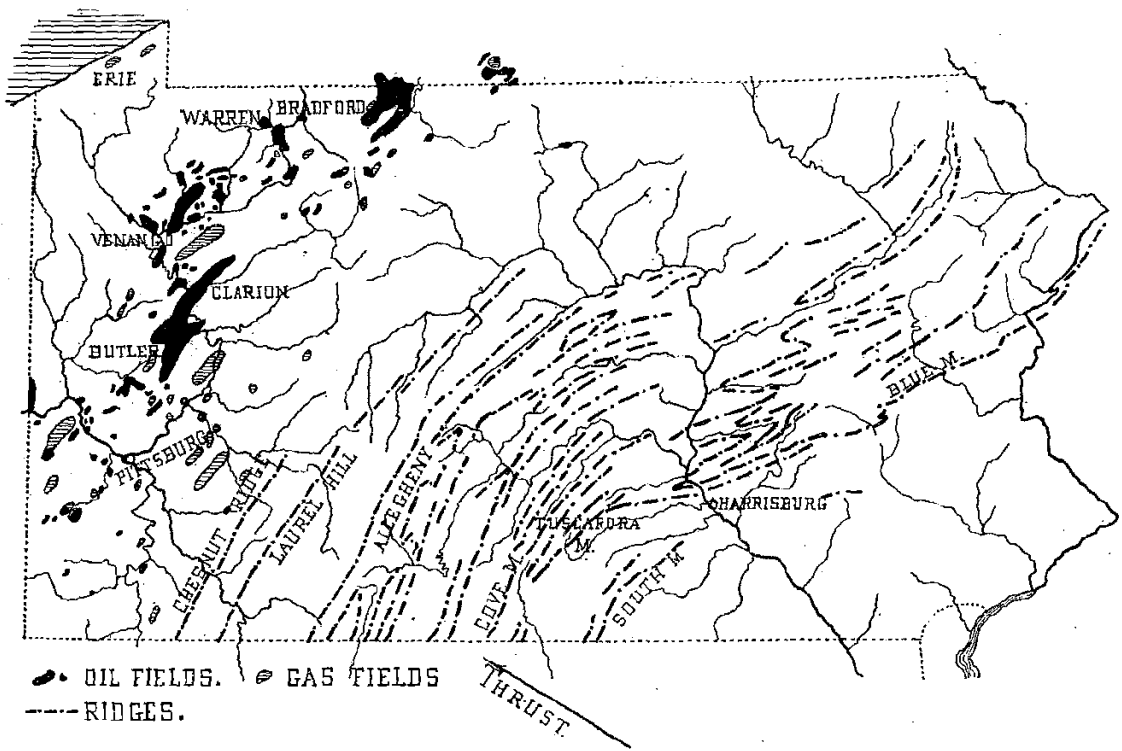

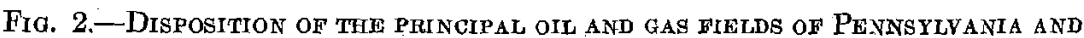
THEIR RELATION TO THE APPALAChIAN RIDGES.

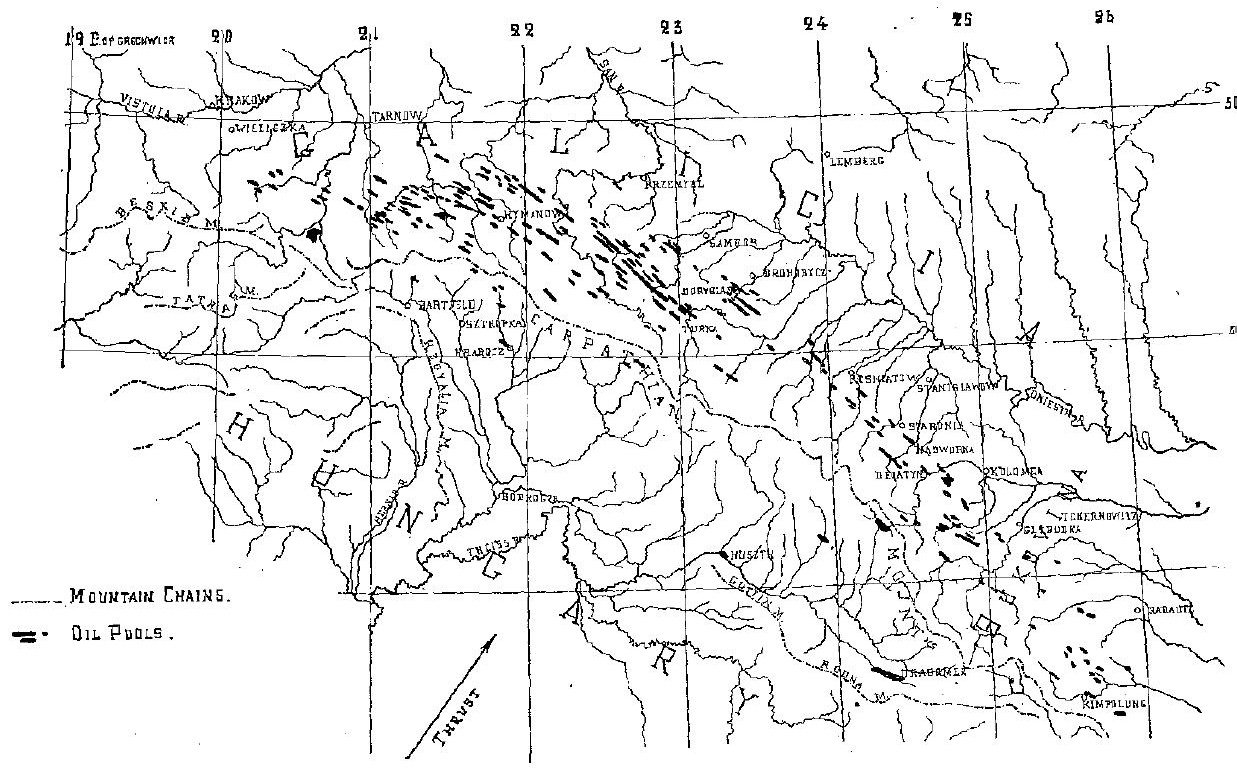

Fig. 3.-Disposícion of the oIl Fieldis of Galicia and Butowina in Relation to physiographic fieatureg. (AFTer Sir Boverton Redwood, Pelroleum, Pl. 2.) 
distortion. In either case, the conformity of the trend of the oil deposits with the lines of deformation is impressive, and this unvaried sameness in the effects brings one naturally to infer an identity of causes. If the thrust had, in both instances, at the same time, shoved and folded the strata and concentrated the hydrocarbons along the lines of lesser pressure, the result would not be different. The writer has developed elsewhere the mechanical process through which such a result may have been brought about. ${ }^{16}$ It is further to be remarked that a common cause

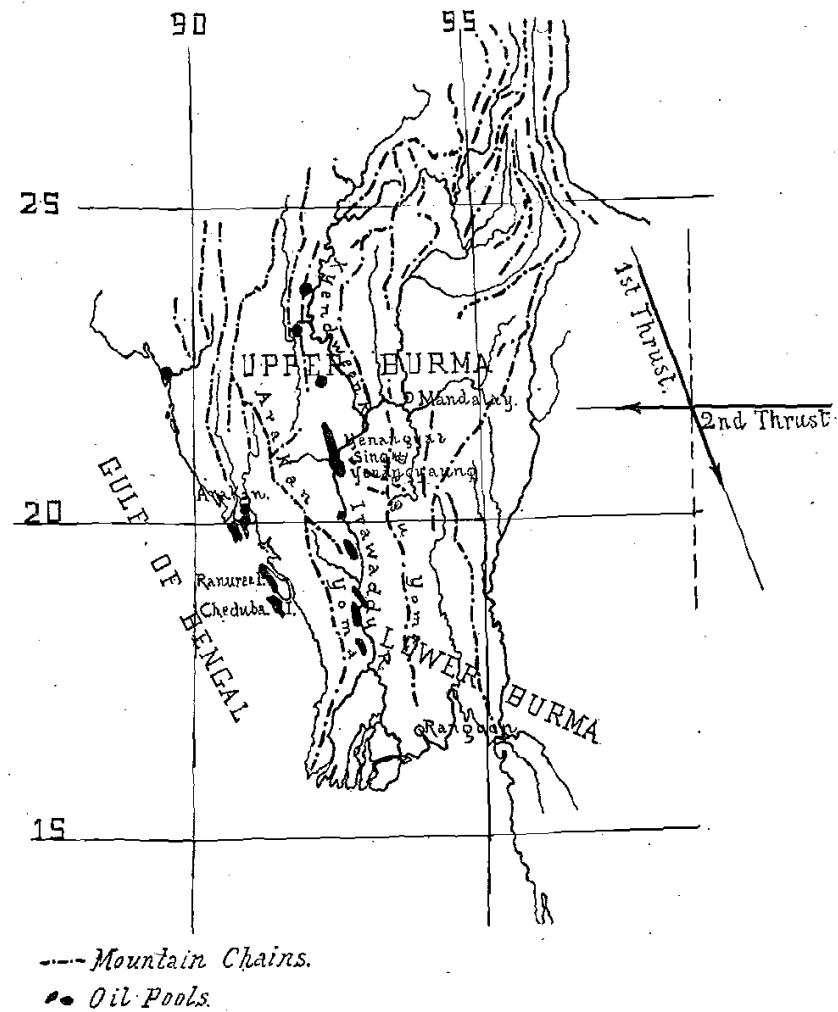

Fig. 4.-OrL Hieldo of Burma.

for earth deformation and hydrocarbon accumulation implies the simultaneousness of the two phenomena. Deformation and accumulation would .thus be related not only in space, but also in time. But should this be true, a further conclusion, by no means less important, would follow. If both phenomena, distortion and accumulation, have, so to speak, a common date, then the bulk of the hydrocarbons must have already existed in the strata when the action of the thrust has taken place, or, in other words, the formation of the hydrocarbons must have anteceded the 
earth's distortion resulting from the thrust, and this formation can in no way be connected with fissures and volcanic phenomena of later date. ${ }^{17}$

Let us now consider a somewhat more complex instance. Fig. 4 is a sketch of the disposition of the Burma oil fields, whose location will be found on the map (Fig. 1) near $92^{\circ}$ long. E. of Paris and $20^{\circ}$ lat. N. The Burma oil fields form two parallel series. The first extends inland along the Kyendween and Lower Irawaddi valleys, between the Pegu-Yoma mountains on the east and the Arakan-Yoma chain on the west; the second follows the eastern shores of the Gulf of Bengal, on the western

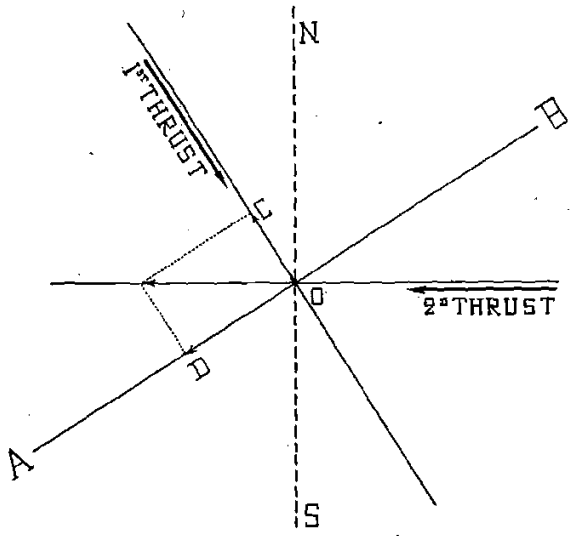

FIG. 5.

side of the Arakan ridge. Both series form a string of isolated deposits, whose course follows the trend of the geosynclinal belt, which runs approximately north-south.

Two flexuring movements have been recognized in this region. An earlier and rather gentle movement caused by a thrust directed from $\mathrm{N}$. $20^{\circ} \mathrm{W}$. to $\mathrm{S} .20^{\circ} \mathrm{E}$, and a later and more important one caused by a thrust directed from east to west. Now, when a series of strata are submitted to two consecutive thrusts coming from two directions inclined at an angle, the first thrust will tend to produce folds normal to its course, like $A B$ (Fig. 5). The action of the second thrust is better understood if this force is decomposed into two components: one, $O C$, normal to the fold

${ }_{17}$ This does not imply that during the simultaneous process of distortion and aceumulation, or after its completion, some new elements may not have been eventually introduced from below, through crevices or fractures, among the already formed hydrocarbons. This would furnish a key to the presence of helium, for instance, in some natural gas, or may help to explain the peculiar composition of the so-called "connate waters," in other places. But such an action could only be secondary, not primary; local, but not general; and the hydrocarbons, as a whole, could not be genetically related with it. In the same way, it frequently happens that lignites or coals, whose organic origin is undeniable, arc locally modified by secondary actions, like dynamometamorphism, or by heat due to the neighborhood of eruptive bodies. 
$A B$ already produced, and the other, $O D$, parallel to it. The first component, $O C$, will simply tend to exaggerate the fold $A B$; the second, $O D$, will compress this fold along its axis. The final result will depend on the relative intensity of the two forces that act in succession and on the angle at which they meet. If the two forces are nearly, at right angle, which would reduce the component $O C$ to a minimum, and if the first thrust is a gentle one, giving rise to large undulations of small relief, while the second is much more powerful, the mean strike lines of final deformation will be in agreement with the second movement. But the resulting folds, instead of being continuous anticlines of great length, will become a succession of shortened anticlines or "elongated domes," separated from each other by depressions corresponding, in a general way, to the synclinal areas of the first flexures. This is precisely what seems to have happened in the Burma region, and the oil fields, the Yenangyung, the YenangyatSingu and others, are located on the resulting "domes." 18

An interesting observation has been made in this connection, that throws some further light upon the relations between deformative movements and hydrocarbon accumulations. ". . . Petroleum," writes E. H. Cunningham-Craig19 "has never been obtained in paying quantity in any field (of the Burma region) that does not show some traces of the earlier movement, even though these traces are often almost obliterated by the much more powerful later movement. It would seem that there has been a preliminary concentration of the petroleum contents of the strata toward the earlier flexures, which concentration has been greatly increased afterward by the later and greater flexuring." This observation tends to make evident that, in this case, accumulation has taken place in two successive and separate stages, each of these being related to a corresponding distinct period of deformation. During the first stage, a first accumulation of Appalachian type would have been formed, by which the hydrocarbons of the surrounding area would have been concentrated away from the thrust and along the lines of lesser pressure, i.e., along anticlinal folds directed W. $20^{\circ}$ S. to E. $20^{\circ}$ N. With the intervention of the second thrust, the concentration would have been completed toward the resulting "domes," which, by the laws of mechanics, would represent the final areas of minimum pressure. Thus, once more deformation and accumulation are found to be related in space and in time. Not only would accumulation have taken place where deformation occurred, and only there, but the two phenomena would have been synchronous and the first would have been essentially dependent on the second.

To sum up: It has been shown that petroliferous deposits, when they are considered as a.whole, are found to be distributed along the principal

18 E. H. Pascoe: The Oil Fields of Burma. Geological Survey of India, Memoirs (1912), 40, 1, PI. 8, 14, 15 and 19.

${ }^{19}$ Oil Finding, 80. 
zones of dislocation of the globe, and more, that deposits of a given age follow the trend of the dislocations of this same age. It has been shown also, that in the three particular instances considered (in the Appalachian, the Carpathian, and the Burmese regions), the relations noted between the petroliferous deposits and the general structure of the ground suggest a common cause for both the deformation and the hydrocarbon accumulation. And finally, it has been remarked that this identity of cause would require the simultaneousness of the effects produced, or, in other terms, that deformation and accumulation would have to be understood as synchronous and closely allied phenomena.

If now we remember: that the three instances quoted refer to three of the most important oil regions of the world; that these regions are widely separated, in three different continents (America, Furope, and Asia); and that the deposits themselves date from various ages (from the Paleozoic to the Tertiary); it becomes evident that the constant relations which have been pointed out cannot be interpreted as local or regional, any more than as transient or exceptional. Their permanent character implies a law of a general order.

There are many oil regions in which these same apparent relations are to be found. But there are also many areas in which the mechanism of distortion has been so complicated as to render its interpretation difficult, at least for the present. So that it would be perhaps too soon to try to formulate this probable law in definite terms. But the facts set forth would at least justify the expression of a working hypothesis, that further investigations may amend or supplement. This is that petroliferous accumulations are generally coincident with diastrophic deformations, synchronous with them, and essentially a result of them.

There are some other remarks that the inspection of the map (Fig. 1) brings forward. The writer wishes to point to one of these: it is the peculiar position occupied by certain oil regions in regard to the trend of the synclinal belt of deformation, such as the region of Borneo, and the area comprising the northeastern coast of Mexico and the Gulf coastal plain region of Texas and Louisiana, farther north. Both regions are located at points where the belt is bent abruptly, and on the inside or concave portion of the curve. Such regions would probably be submitted to pcculiar stresses. Besides flexuring by compression, there would be a tendency to deformation by torsion. Daubrée's experiments have shown that torsion may give rise to a system of conjugated faults, equally inclined on the principal axis of torsion. It is significant that if, on one hand, the lines of fractures, resulting in igneous dikes and intrusions, of the Mexican oil fields, ${ }^{30}$ and, on the other hand, the faults of the Gulf coastal plain region (whether ascertained faults or hypothetical faults

${ }^{20}$ Huntley: Trans. (1915), 52, 302, Fig. 2; and 310, Fig. 6. 
according to the views of Harris), ${ }^{21}$ are recorded on the map, they present essentially the appearance of a continuous system of the kind. What may have been the influence of such deformation, combined with deformations due to other causes, on the accumulation of the oil, is still to be seen. But that some kind of relation would exist, is probable in the opinion of the writer. Should this point ever be investigated, it would be prudent to remember that the two groups of conjugated lines (right and left) of Daubrée's experiments are not identical in value. When a

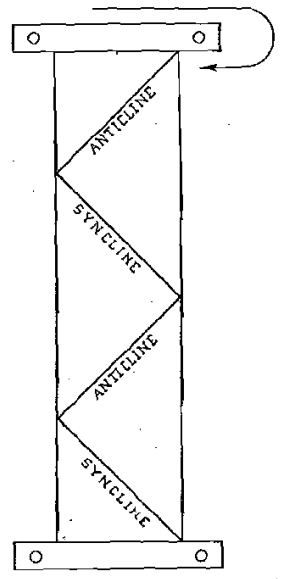

FIG. 6.

flexible sheet, instead of the rigid glass plate used by Daubrée, is submitted to torsion, the motion following the direction of the hands of the clock, the lines of deformation will appear as indicated in Fig. 6. One set is concave (synclinal), the other is convex (anticlinal). If the torsional movement is reversed, the lines will be symmetrically reversed also. Thus, torsion may give rise to flexures; and wherever it produces faults, one set of these would have a tendency to open from above and the other set from below, the maximum relief of stresses being found at the crossing points of the two sets.

\section{Discussion}

W. van Der Gracht, Tulsa, Okla. (written discussion*).-I fully agree with Mr. Daly's observation that there is such a coincidence between petroleum deposits and geosynclines as to suggest them to be "closely allied phenomena." However, I accept no "identity of cause.". To me the explanation is a simple one.

${ }^{21}$ G. D. Harris: U. S. Geological Survey Bulletin No. 429.

* Received Oct. 10, 1917. 
Geosynclinal deposition is the first phase in the formation of a mountain chain, and petroliferous deposits are indeed closely allied to zones of mountain folding. In fact, petroleum is a typical occurrence in those beds, which represent the flysch facies, to use the Swiss expression. The uplifting of a great mountain chain is a very slow process; it gradually sets in as a slow geo-anticlinal upheaval within a zone of former geosynclinal deposition. This uplift is immediately attacked by intense erosion as its crest rises out of the geo-synclinal sea, and this erosion causes intensive deposition of lagunary and shallow-water deposits in the adjacent sea, in front of the push, where the bottom continues to sink. As a rule, this deposition keeps up fairly well with the subsidence, maintaining very shallow-water marine conditions alternating with brackish and fresh-water conditions. This goes on during a long time, causing a great thickness of such deposits as shales with numerous sandstones and limestones. This is the typical fysch facies, i.e., shallow, quiet-water, marine deposits, alternating with lagunary, sometimes saline, and even fresh-water deposits, the latter often containing numerous coal beds. Such deposits contain all the large coal-bearing as well as oil-bearing areas of the world. Wherever there were swamps capable of maintaining heavy vegetation, great bog deposits were laid down, which, after they had been buried by a renewed subsidence, were fossilized into coal beds. Further out, in the shallow sea, often behind sand bars, great masses of plancton accumulated, followed naturally by an abundance of other marine life, which lived on this plancton, and by others which in turn preyed on the first. Thus, a mud that was largely organic was laid down, which gradually was to become an oil shale-the primary container of petroleum.

All this, as I said, happened in the early stage of the formation of a mountain chain. If conditions remained thus, we got a coal field or deposit of oil shale, but no oil field. If, however, the mountain-building forces continued, and the final phase of great folding was consummated, the $f y s c h$ beds were thrown into anticlinal and synchinal folds; the primary oil moved out of the disturbed oil shales and, if an adequately porous container were present, accumulated in the tops of the anticlines, making an oil field. These naturally are found mostly on the front edge of the original geosynclines, because in the heart of the mountains the flysch deposits-if ever they were formed-have been destroyed by the overthrusting and sharp folding and subsequent very intensive erosion. Only on the outer edge of the zone of folding, the fysch anticlines have had a chance to be preserved as oil containers.

Thus geosynclines and oil fields are indeed "allied phenomena" but there is "no identity of cause." They are really "coincident" with diastrophic deformations and more or less "synchronous," but synchronous only within a certain phase - the formation of bituminous matter in 
its primary form is coincident only with the earliest phase of the uplift of a mountain chain, the accumulation with the final phase of acute actual folding.

Thus, to cite a few instances, the Carboniferous oil is mainly Pennsylvanian all over the world, in the flysch deposited before the great late Carboniferous, early Permian final folding; the Cordillerian petroleum of America is Upper Cretaceous, again in the flysch deposited before the final folding of the Rocky Mountains and the Andes in the early Eocene. These examples could be repeated indefinitely for all mountain chains, and they will more or less clearly explain almost every larger oil field the world over.

Frederick G. Claapp, New York, N. Y. (written discussion*).-We have all agreed for years with Mr. Daly's italicized statement on page 1064, "that petroliferous accumulations are generally coincident with diastrophic deformations, synchronous with them, and essentially a result of them." In other words, oil pools correspond with localities of suitable structure, into which the oil was segregated on account of the doming or other structural processes. This is the structural theory, pure and simple, and does not commit us further than this to the so-called diastrophic theory.

As to the paper itself; why might it not be equally well entitled "Geanticlines and Petroliferous Deposits?" Certainly oil occurs on more geanticlines than geosynclines; and the axes mapped on Fig. 1 of the paper are those of geanticlines.

It seems to me, without wishing to criticize the thought and care bestowed on the paper, that the matter has been unnecessarily complicated in its exposition; and that his enthusiasm may have led the author far beyond his better judgment. In studying Fig. 1, for example, we find that in Virginia, Florida, China, Newfoundland, France, the British Isles, and many other localities, petroliferous deposits are represented which are in some cases mythical and in others proved to be of no value, being justified only by their previous appearance on Boverton Redwood's published map. Some great oil fields like those of Oklahoma, Illinois, Louisiana, Pennsylvania, etc., are situated hundreds or thousands of miles from the "geosynclines" (geanticlines) as mapped in other parts of this plate.

The author's statement, of course, is true that in most oil fields two sets of thrusts seem to have taken place. This is especially noticeable in Oklahoma and Wyoming, where what are known as "cross anticlines" are frequent. These may be due to the succession of two or more sets of forces operating in different directions, to torsion, as explained on page 1065 , or to some sort of thrust from below, quite different from lateral 
causes, as in the Louisiana, Transylvanian, some Mexican, and the Roumanian fields. But to the modern petroleum geologist, cause is of little importance; it is the presence of suitable structure, underlain by porous sands and accompanied by other favorable conditions, that are important.

Marcel R. Daty (written discussion*).-I have read with great interest Mr. W. van der Gracht's discussion of my paper and I fail to see where his theory contradicts mine on any fundamental point. My contention is that petroliferous accumulations are generally coincident with diastrophic deformations, synchronous with them, and essentially a result of them. This implies that the causes which have led to the distortion of the strata, whatever these causes may be (thrusts, torsion, etc.), have also led to the concentration and accumulation of the hydrocarbons existing in the strata at that time. It is in this respect that both sets of phenomena may be said to be related in space and in time and that we may speak of an identity of causes. It is evident that no concentration of the hydrocarbons could take place where these hydrocarbons would not exist. But whenever they do so exist, deformation will tend to concentrate them; and whenever they are found to be concentrated (or accumulated) the cause of their accumulation will have to be traced directly to distortion. I have tried to show, in some previous papers, ${ }^{1}$ the probable sequence of such a mechanical process in the simple case of a series of parallel, superposed, horizontal, and homogeneous layers, individually uniform in thickness, but variable in composition and resistance; and I have pointed out that the general results so obtained would harmonize with some striking features recognized in the field. But I have also stated that conditions being much more complicated in nature than in the theoretical instance considered above, a complex superposition of effects would have to be expected as a general rule, though the leading principle would remain the same.

Mr. van der Gracht admits that the motion of the primary oil, when it has been formed, and its accumulation in adequately porous containers, if any, that would be mostly found on the front edge of the original geosynclines, would be due to the action of the mountain-building forces. Our agreement on this point seems to be complete. But Mr. van der Gracht wants also the formation of the bituminous matter in its primary form to be coincident only with the earliest phase of the uplift, viz., after the slow geanticlinal upheaval has been completed, and the accumulation of oil to concur only with the final phase of acute actual folding. It seems to me that this conception covers only a special case. There is no reason

* Received Jan. 29, 1918.

${ }^{1}$ Diastrophic Theory. Trans. (1916), 56, 733, 760. Geosynclines and Petroliferous Deposits is a sequel. 
a priori for denying the possibility of the accumulation of the parent matter from which oil proceeds, on the rims of the geosyncline itself, during the period of erosion and deposition that brings about its filling. Mr. van der Gracht's theory is probaby true for the fields of Central Europe, for instance, where the "flysch facies" is so characteristic; but it is difficult to see how it could be applied in some other cases, for instance to the Burma fields, where the oil formations are deltaic. ${ }^{2}$ Here, as pointed out by the writer, two successive flexuring movements have been recognized, and it has been shown ${ }^{3}$ that a first accumulation of the oil has taken place contemporaneously with the first set of flexures, the direction of which is normal to the general geosynclinal trend. The consequence is that the second flexuring movement, precisely the one that would create waves parallel to the geosynclinal axis, must have acted on the already partially accumulated hydrocarbons during its entire duration, not merely at its close.

Mr. van der Gracht seems to consider an oil shale, in a general way, as the primary container of petroleum. I think a distinction is to be made between an oil-bearing shale, where the primary oil may have remained in a state of dissemination, by reason of some interruption in the folding process or even by the lack of it, and an oil shale proper, or "kerogen shale," from which shale oil is extracted, as in the Lothians, New South Wales, and elsewhere. In a recent paper, to which I have had already occasion to refer," Cunningham-Craig has clearly shown that the bituminous matter contained in a "kerogen shale" is the result of the inspissation of an already concentrated petroleum and of its further adsorption by argillaceous material. The "kerogen" phase would thus represent a later phase than the oil phase, and kerogen-shale fields would be the descendants of oil fields and not their forefathers. The distinction is economically important.

Answering Mr. Frederick G. Clapp: The writer feels gratified thàt Mr. Clapp should agree with his statement that "petroliferous accumulations are coincident with diastrophic deformations, synchronous with them, and essentially a result of them," but unfortunately $\mathbf{M r}$. Clapp does not give to this statement the same interpretation as the writer himself, when he adds: "In other words, oil pools correspond with localities of suitable structure, into which the oil was segregated on account of the doming or other structural processes." This may answer to the first part of the proposition, which implies the coincidence of accumulation with certain

2 "The Pegu Series of Burma, ranging from the Eocene far up into the Miocene according to our subdivisions of Tertiary time, furnishes perhaps the most conclusive evidence of the advance of a delta that has been worked out in any detail" (C. Craig: Oil Finding, 63).

${ }^{3}$ See p. 1063.

${ }^{4}$ See p. 1054. 
structural forms, but it omits the two factors of synchronization and causality, or at least it throws in doubt their intervention. If the writer's formula is accepted it ought to be accepted with its full meaning, and the logical consequences of these premises would have to be accepted at the same time. It has been the aim of the writer, in his "Diastrophic Theory," to show what these consequences may be.

The paper has been entitled "Geosynclines and Petroliferous Deposits" for the reason that the writer studies in this paper the mutual relations between the loci of deposition of the hydrocarbons and the "zones of weakness and mobility of the earth," geosynclines by definition ( $p$. 1055). The geosynclines of the Mesozoic Era, represented on Fig. 1, have been drawn according to the views of Prof. E. Haug, of Paris, one of our leading European geologists (p. 1056).

The deposits mapped on Fig. 1 do not represent workable oil fields exclusively. The writer has taken great care to specify that, in the paper as well as on the map, no attempt was made to distinguish between the different members of the petroleum family, which are treated as a whole (Petroliferous Deposits), nor to set off the respective importance of the deposits themselves (pp. 1054, 1055, 1058). Hence, the remark on the lack of economic value of some of these deposits does not apply. Economic importance alone is not a sufficient criterion in determining the geological interest of a landmark.

Coming to the question of distance between the great oil fields of Pennsylvania, Illinois, and Oklahoma, and the geosynclines mapped on Fig. 1, the writer refers Mr. Clapp to the legend inscribed on the plate and to the description of the latter (pp. 1056-58). The geosynclines represented are those of the Mesozoic Era, and Paleozoic deposits would have no necessary connection with them. These Paleozoic deposits would be related to a different system or "geosynclinal network," and, for this reason, their distance from any other system is immaterial. This is precisely one of the conclusions represented by the writer (p. 1059, italicized statement). As for the Louisiana field, the writer has himself drawn attention to its peculiar position, and has advanced a hypothesis to explain it (pp. 1064-65).

Finally, the writer begs to take exception to the remark that "to the modern petroleum geologist, cause is of little importance." If the search of causes is of no value, then Newton would have been satisfied that the apple dropped from the tree because it wanted to. I wonder what would have become of our modern art of mining if it had been left, without any further research of causes, in the shape in which Agricola found it in the sixteenth century, when he was writing his treatise" De Re Metallica." 